IZABela Olejnik

Uniwersytet Wrocławski

\title{
STAN BADAŃ NAD LITERATURĄ ZAGŁADY NA PRZYKŁADZIE LITZMANNSTADT GETTO. ProjeKT BIBLIOGRAFII GETTA ŁÓDZKIEGo
}

\section{Wstęp}

Sześćdziesiątej piątej rocznicy likwidacji getta łódzkiego w 2009 roku towarzyszyła promocja publikacji najważniejszego dokumentu czasów Zagłady, powstałego w okresie okupacji hitlerowskiej w Łodzi. Mowa oczywiście o wydaniu pełnej wersji Kroniki Getta Łódzkiego. Pełnej, ponieważ dotychczas badacze mieli do dyspozycji zaledwie dwa tomy opracowane przez Lucjana Dobroszyckiego i Danutę Dąbrowską ${ }^{1}$. Dążenia redaktorów do wydania kolejnych tomów przerwały wydarzenia marca 1968 roku. Musiało upłynąć ponad czterdzieści lat, by do rąk czytelników trafiła kolejna jej edycja. Wśród wydarzeń towarzyszących uroczystym obchodom były liczne spotkania, wykłady, prezentacje. Publikacja kroniki stała się także bodźcem do zorganizowania w Warszawie w Centrum Badań nad Zagładą Żydów IFiS PAN dyskusji pod hasłem „Skąd to milczenie nad łódzkim gettem? Kronika Getta Łódzkiego - źródło do dziejów getta”2. Jedną z kwestii,

${ }^{1}$ Kronika Getta Łódzkiego. t. 1, Styczeń 1941 - maj 1942, z oryg. do dr. przygot., wstępem i przypisami opatrzyli Danuta Dąbrowska i Lucjan Dobroszycki, Łódź 1965; Kronika Getta Łódzkiego t. 2, Czerwiec - grudzień 1942, z oryg. do dr. przygot., wstępem i przypisami zaopatrzyli Danuta Dąbrowska i Lucjan Dobroszycki, Łódź 1966.

${ }^{2}$ Zapis audio dyskusji [online], [dostęp: 23.07.2013]. Dostępny WWW: http://www.holocaustresearch.pl/index.php?show $=471$ \&lang $=\mathrm{pl}$ 
którą zamierzano podnieść w czasie seminarium, była próba wyjaśnienia przyczyn milczenia i uzyskanie odpowiedzi na pytanie, dlaczego badacze tak rzadko podejmują tematykę getta łódzkiego w swoich badaniach.

Celem niniejszej pracy jest prześledzenie światowego piśmiennictwa poświęconego historii Litzmannstadt Getto istniejącego w Łodzi w latach 1940-1944, przedstawienie aktualnego stanu badań nad gettem łódzkim a nade wszystko wyjaśnienie powodów, dla których historiografia Zagłady milczy na temat getta łódzkiego i czy słuszne jest postawienie takiego pytania. Przedstawiona w tekście analiza powstała w dużym stopniu w oparciu o przygotowywaną bibliografię getta łódzkiego, o której piszę w dalszej części tekstu.

\section{Piekło Litzmannstadt Getto}

Getto łódzkie było jednym z pierwszych gett utworzonych na okupowanych ziemach polskich. W dniu 8 lutego 1940 roku gazeta „Lodzer Zeitung” zamieściła zarządzenie prezydenta policji, Johanna Schäfera, o utworzeniu w mieście wydzielonej dzielnicy mieszkaniowej dla Żydów. Na miejsce tej dzielnicy naziści wybrali najbardziej zaniedbaną część północnej Łodzi tj. Bałuty oraz Stare Miasto. Jej obszar wynosił $4,13 \mathrm{~km} \mathrm{kw.}{ }^{3}$.

Niecałe trzy miesiące później granice getta zostały zamknięte. Dookoła getta w odległości co 100 metrów stali niemieccy żołnierze. Mieli rozkaz strzelać do każdej osoby, która chciałaby zbiec bądź zbliżałaby się do drutów okalających getto. Wokół getta stały tablice z napisem „Wohngebiet der Juden Betreten Verboten” (Żydowska dzielnica mieszkaniowa. Wejście wzbronione).

Naziści, decydując się na usytuowanie getta właśnie na Bałutach, ucięli ewentualne próby przedostania się na stronę aryjską. Na długo przed wybuchem wojny Bałuty zamieszkiwała biedota żydowska. Zarówno Bałuty jak i Stare Miasto nie były skanalizowane, dlatego nie mogło być mowy o ucieczce z getta kanałami. Poza tym Łódź zamieszkiwała ponad 70-tysięczna mniejszość niemiecka, która była lojalna wobec nowych władz. Wszystkie te czynniki złożyły się na to, że łódzkie getto było „bardziej szczelne i lepiej strzeżone od pozostałych gett utworzonych przez III Rzeszę. Odbiło się to tragicznie na życiu jego mieszkańców, gdyż prawie całko-

${ }^{3}$ J. Baranowski, The Lodz ghetto 1940-1944: vademecum = Lodzkie getto 1940-1944, Łódź 2009, s. 31. 
wicie uniemożliwiło szmugiel żywności i lekarstw" ". W chwili zamknięcia getta w jego granicach stłoczono 160320 Żydów, z czego 153849 stanowili żydowscy mieszkańcy miasta.

Na wzrost śmiertelności w getcie w decydujący sposób wpłynął przymus pracy. Obowiązkiem pracy zostały objęte osoby od 10. do 65. roku życia. „Praca odbywała się w ciężkich warunkach lokalowych, przy zaostrzonym rygorze i dyscyplinie; jej czas, wynoszący nominalnie 10 godz. dziennie, często przedłużano do 12, a nawet 14 godzin. Za tę niewolniczą pracę, przynoszącą okupantowi ogromne zyski, robotnik otrzymywał znikome wynagrodzenie"s.

Mimo wszystko praca w getcie była niezwykle ważna. Niedługo po zamknięciu getta wprowadzone zostały specjalne kartki oraz kupony. Kto je posiadał, otrzymywał przydział racji żywnościowych oraz opału, najpierw na miesiąc potem na dwa tygodnie. Niestety, ani racje, ani wynagrodzenie otrzymywane za pracę nie wystarczały na zakupienie takich ilości pożywienia, by nie cierpieć z powodu głodu. Głód w getcie stawał się coraz bardziej dotkliwy i coraz trudniej było go znosić.

Dodatkową przeszkodą w zdobywaniu pożywienia nielegalną drogą była waluta, która obowiązywała tylko na terenie getta łódzkiego tzn. bony markowe, będące jedynym środkiem płatniczym. Pieniądze te poza granicami getta nie miały żadnej wartości. Powszechnie nazywano je „rumkami”, od nazwiska Przełożonego Starszeństwa Żydów.

Jesienią 1941 roku rozpoczął się proces wsiedlania do getta łódzkiego Żydów z Europy Zachodniej, w tym z Berlina, Pragi, Wiednia i Luksemburga. W przeciągu niespełna miesiąca do getta trafiło 19954 Żydów 6 . Zostali oni zakwaterowani w dawnych budynkach szkolnych. Tym samym wszelkie oficjalne szkolnictwo w getcie przestało istnieć. Co prawda pojawiały się pogłoski o rzekomym reaktywowaniu szkół, ale nigdy tak się nie stało. Tym bardziej, że w następnych miesiącach 1941 roku do getta przybyło blisko 18000 Żydów ze likwidowanych gett prowincjonalnych m.in. z Pabianic, Brzezin, Strykowa, Włocławka, Sieradza oraz Wielunia.

Ponadto w granicach getta naziści utworzyli dwa odizolowane obozy. Jeden był przeznaczony dla Cyganów, a drugi dla dzieci oraz młodzieży polskiej.

Najtragiczniejszą kartą w historii getta łódzkiego był okres między 3 a 12 września 1942 roku powszechnie znany jako „szpera”. To właśnie wtedy

\footnotetext{
4 Tamże, s. 33.

5 Tamże, s. 81.

6 Tamże, s. 33.
} 
Mordechaj Chaim Rumkowski zwrócił się do mieszkańców getta ze swoim słynnym przemówieniem „Oddajecie mi swoje dzieci”. W czasie tych kilku dni mieszkańców getta obowiązywał zakaz wychodzenia $\mathrm{z}$ domu, resorty wstrzymały pracę. Z getta miały zniknąć wszystkie dzieci poniżej 10. roku życia, chorzy i osoby niepracujące, czyli tzw. element nieprzydatny, którego dalsze utrzymywanie przy życiu nie przyniosłoby żadnych korzyści finansowych III Rzeczy. Dzienny kontyngent miał wynosić 3000 osób. Żydowscy policjanci w asyście Niemców chodzili od domu do domu i wyciągali tych, których nazwiska były na listach transportowych.

Po szperze życie w getcie na pewien czas wróciło do „normalności”, tyle tylko, że nie było w nim dzieci. Resorty wznowiły pracę, rozpoczęto realizację kolejnych zamówień. Zgodnie z zarządzeniem Niemców w getcie mogli pozostać tylko ci, którzy byli w stanie jeszcze pracować. Ten względny spokój nie trwał długo. Kolejne deportacje zostały wznowione w maju 1944 roku. Wtedy Niemcy zadecydowali o likwidacji łódzkiego getta. Przyczyną takiej decyzji był najprawdopodobniej sukces kwietniowo-majowej ofensywy armii radzieckiej, co pogorszyło sytuację wojsk niemieckich na ziemiach polskich. Ostatnim transportem, tj. 29 sierpnia 1944 roku, odjechał wraz z rodziną i innymi mieszkańcami getta sam Mordechaj Chaim Rumkowski.

\section{Przegląd piśmiennictwa na temat getta łódzkiego}

Literatura poświęcona Zagładzie łódzkich Żydów jest niezmiernie bogata i różnorodna. Przeprowadzone dotąd badania nad gettem łódzkim pokazują szerokie spektrum podejmowanych tematów. Pierwsze prace traktujące o doświadczeniu Zagłady zaczęły powstawać zaraz po zakończeniu działań wojennych. Zadaniem utworzonej w 1945 roku Centralnej Żydowskiej Komisji Historycznej (CŻKH), powstałej w ramach Centralnego Komitetu Żydów w Polsce (CKŻP), było dokumentowanie zbrodni niemieckich dokonanych na Żydach, zbieranie relacji w oparciu o opracowany przez CKŻP kwestionariusz oraz przygotowywanie ich do druku?

W latach 40. XX wieku na temat getta łódzkiego ukazało się 26 prac o charakterze naukowym oraz wspomnieniowym. Część z nich opublikowano w formie wydawnictw książkowych, inne zaś na łamach czasopism żydowskich jak np. „Bleter far Geszichte”, które Żydowski Instytut Historyczny

${ }^{7}$ J. Tomaszewski, Polish historiography on the Holocaust [w:] Nazi Europe and Final Solution, red. D. Baner, I. Gutman, Jerusalem 2003, s. 111. 
zaczął wydawać od 1947 roku bądź w miesięczniku „Jidisze Szriftn”, które, jak podaje badaczka literatury jidysz Magdalena Ruta, „było zdominowane przez tematykę Zagłady”, tworząc swego rodzaju Księgę Pamięci ${ }^{8}$. Przeważająca większość powstałych w tym czasie prac ukazała się w języku jidysz, co pozostaje nie bez znaczenia przy ich wykorzystaniu w badaniach. Grono badaczy, którzy mogą pochwalić się znajomością języka jidysz jest w dalszym ciągu niewielkie. Tym bardziej cieszą opracowania, które powstały przy wykorzystaniu bogatych i przez długi czas niewykorzystanych źródeł właśnie w tym języku. Przykładem jest choćby monografia getta łódzkiego autorstwa Jeszajahu Trunka Lodżer geto: a historisze un socjologisze sztudie mit dokumentn, tabeles un mape wydana w 1962 roku w Nowym Jorku. Jak zauważył tłumacz tej monografii, Robert Szapiro, praktycznie żaden z polskich badaczy w swoich dotychczasowych publikacjach ani razu nie zacytował pracy o getcie łódzkim w języku żydowskim czy hebrajskim, nie wspominając dzieła Trunka9.

Ciekawostką są dwie publikacje traktujące o getcie łódzkim, które ujrzały światło dzienne jeszcze w czasie istnienia getta. Pierwszą z nich jest Lodżer izker-buch, księga pamięci poświęcona Łodzi, opublikowana w 1943 roku w Nowym Jorku staraniem tamtejszego ziomkostwa ${ }^{10}$. Łódzka księga otwiera cykl poświęcony zgładzonym społecznościom żydowskim w czasie II wojny światowej. Łódź należy do tych kilku miast, którym poświęcono kilka ksiąg. Cztery z nich ukazały się w jidysz, dwie zaś dostępne są w języku hebrajskim. Żaden $\mathrm{z}$ tych tomów do dziś nie doczekał się przekładu nawet na język angielski. Ze względu na ich unikatowość, charakter i jak dotąd brak jakiegokolwiek opracowania omawiam je w dalszej części tekstu.

$\mathrm{Z}$ tego samego roku pochodzi The Black Book of Polish Jewry. Intencja jej redaktorów było poruszenie dramatyczną sytuacją ludności żydowskiej

${ }^{8}$ M. Ruta, Tematy literatury jidysz w latach 1945-1949 [w:] Nusech Pojln: studia $z$ dziejów kultury jidysz w powojennej Polsce, pod red. M. Ruty, Kraków 2008, s. 250.

9 R. M. Shapiro, Introduction [w:] Łódź ghetto: a history, Isaiah Trunk, Bloomington 2006, s. 18.

${ }^{10}$ Ziomkostwo (jid. Landmanszaft) - wspólnota grupująca żydowskich emigrantów pochodzących z jednego regionu lub miasteczka. Powstawały w Stanach Zjednoczonych, Palestynie, począwszy od 1880 wraz z masową falą emigracji. Miały charakter nieformalny, głównie towarzyski i samopomocowy. Wspomagały czasem rodaków w starym kraju. Ziomkostwa tworzone były w czasie okupacji w gettach, w środowiskach osób przesiedlonych, które utraciły cały dobytek. Organizowały samopomoc. Szczególnego znaczenia nabrały po II wojnie światowej, gdy Żydzi ocaleni z Zagłady rozproszyli się po świecie. Pomagały odszukać krewnych, przeciwdziałały poczuciu osamotnienia i zagubienia w nowym kraju. Przede wszystkimkultywowały pamięć o rodzimym sztetl. Wydawały „Księgi Pamięci”. Zob.: A. Cała, H. Węgrzynek, G. Zalewska, Historia i kultura Żydów polskich: słownik, Warszawa 2000, s. 376. 
w gettach i obozach koncentracyjnych oraz ich fizyczną zagładą opinii publicznej, która była „zbyt nieświadoma piekła, w którym ginęło setki tysięcy Żydów wskutek ciosów zadanych przez barbarzyńskich oprawców a także zniszczenia bezcennego materialnego i duchowego bogactwa, do którego polscy Żydzi przez wieki wnosili swój wkład"11. To także jeden z powodów, dla których redaktorzy zdecydowali się poświęcić tom polskim Żydom, choć zdawali sobie sprawę z tego, że skala Zagłady wykracza poza granice okupowanej Polski. Informacje dotyczące Łodzi otwiera szczegółowy opis prześladowań, jakich doznali Żydzi od momentu zajęcia miasta przez wojska niemieckie, tj. grabież mienia, aresztowanie członków gminy żydowskiej, stosunek lokalnych folksdojczów do Żydów, uliczne łapanki, strzyżenie bród na ulicach, zniszczenie synagog oraz pomnika Tadeusza Kościuszki czy aresztowanie inteligencji żydowskiej w kawiarni Astoria. Redaktorzy przytaczają dekrety antyżydowskie, które odtąd miały obowiązywać żydowskich mieszkańców Łodzi. Informacje dotyczące getta koncentrują się na utworzeniu dzielnicy żydowskiej na Bałutach, ale znajdziemy tam też przekaz o katastrofalnych warunkach, w jakich żyli ludzie, których wkrótce zaczęły dziesiątkować nie tylko choroby czy epidemie, ale także głód. Mimo że opis getta łódzkiego obejmuje dwa pierwsze lata jego istnienia, stanowi cenne źródło badań.

Staraniem CKŻP już w 1946 roku wydano w serii Dokumenty i Materiały do Dziejów Okupacji Niemieckiej w Polsce zbiór dokumentów dotyczących getta łódzkiego w opracowaniu Artura Eisenbacha. Oprócz tej wspomnianej publikacji CKŻ wydała jeszcze trzy książki poświęcone gettu łódzkiemu, $\mathrm{w}$ tym jeden poemat ${ }^{12}$ oraz dwa opracowania ${ }^{13}$.

Na łamach „YIVO Bleter” w 1947 roku ukazał się artykuł Beneta Hershkovitcha. Hershvoitch napisał swój tekst w Szwecji w kwietniu 1946 roku, jednak do rąk czytelników trafił on dopiero rok później. Autor, były mieszkaniec getta łódzkiego, „,na gorąco” spisał swoje wspomnienia. Tekst ten jest niewątpliwie ważny dla dziejów getta, jednak oparty wyłącznie na wspomnieniach, co wymaga równoległego czytania z opracowaniami naukowymi.

${ }^{11}$ J. Apenszlak, Editor's foreword [w:] The Black Book of Polish Jewry: an account of the martyrdom of Polish Jewry under Nazi occupation, New York 1943, s. 8.

${ }_{12}$ S. Szajewicz, Lech - lecho: araynfir un bamerkungen fun Nahman Blumental, Łódź 1946.

${ }^{13}$ N. Blumental, Słowa niewinne: [słownik wyrazów oznaczających bestialstwa hitlerowskie, m.in. dotyczy getta w Łodzi], Kraków 1947; A. Melezin, Przyczynek do znajomości stosunków demograficznych wśród ludności żydowskiej w Łodzi, Krakowie i Lublinie podczas okupacji niemieckiej, Łódź 1946. 
Pod koniec tej dekady w Nowym Jorku ukazał się zbiór reportaży Europa - między wojna a pokojem ${ }^{14}$ autorstwa Pejsacha Nowika, który na przełomie 1946 i 1947 roku odbył trwającą kilka miesięcy podróż po Europie. W Polsce spędził trzy miesiące, dokumentując odbudowujące i odradzające się życie żydowskie w powojennej rzeczywistości. Jego opis dotyczący Łodzi a w szczególności getta łódzkiego, jest jedną z pierwszych informacji żydowskich o getcie, jaka dotarła na Zachód.

To, co wyróżniało te pierwsze badania nad Holocaustem to zdaniem historyka Jerzego Tomaszewskiego „dążenie do zebrania dokumentów oraz publikacja pewnej najważniejszej ich części. Wynikało to z przekonania o tym jak ważne jest odnalezienie, zebranie a następnie ochrona tych dokumentów przed zniszczeniem - przypadkowym czy zamierzonym - oraz zebranie relacji tak długo jak wydarzenia, które rozegrały w czasie okupacji wciąż pozostają żywe w pamięci”"15. Dodatkowo z końcem lat czterdziestych większość artykułów była publikowana głównie w czasopismach Żydowskiego Instytutu Historycznego (ŻIH). Jako że spora część odbiorców nie znała języka żydowskiego, można było odnieść wrażenie, że te publikacje były zarezerwowane głównie dla żydowskich czytelników ${ }^{16}$. Zaważył na tym, zdaniem prof. J. Tomaszewskiego, czynnik nieznajomości języka jidysz, który uniemożliwił polskim badaczom analizowanie źródeł w tym języku, przez co wszelkie źródła w jidysz automatycznie stawały się dla nich niedostępne. Drugim czynnikiem, o którym nie wolno zapomnieć, była panująca $\mathrm{w}$ tym czasie atmosfera polityczna i klimat pisania pod dyktando nowej władzy.

W stosunku do lat powojennych liczba publikacji o tematyce getta łódzkiego, które ukazały się w latach pięćdziesiątych jest mniejsza. Ogółem na ten okres przypada około dwudziestu publikacji wydanych w Polsce i za granicą. Staraniem ŻIH-u ukazało się kilka ważnych prac dotyczących getta, spośród których wymienić należy m.in. artykuł Danuty Dąbrowskiej o Żydach z Kraju Warty wsiedlonych do getta łódzkiego czy publikacje Anny Kubiak, która swój artykuł poświęciła tzw. „szperze”. W 1949 roku na łamach „Commenary” Salomon Bloom zamieścił artykuł o Przełożonym Starszeństwa Żydów w getcie łódzkim pod znamiennym tytułem Dictator of the Lodz ghetto: the strange history of Mordechai Chaim Rumkowski. Na temat Chaima Rumkowskiego, postaci bardzo niejednoznacznej, kontrower-

14 P. Nowik, Ejrope - cwiszn milchome un szolem (Europa - między wojna a pokojem), Nowy Jork 1948.

15 J. Tomaszewski, Polish historiography..., s. 114.

16 Tamże, s. 114. 
syjnej, budzącej w środowisku badaczy sprzeczne emocje powstało dotąd ponad pięćdziesiąt opracowań, poczynając od bardzo krytycznych, w których pisze się o nim jako o głupcu i pomocniku katów, po bardziej łagodne w ocenie, w których autorzy odsuwają swoje opinie a koncentrują się na przedstawieniu jego aktywności w getcie łódzkim. Często porównuje się go z Adamem Czerniakowem - prezesem getta warszawskiego - który zorientowawszy się, czym są „przesiedlenia”, nie zgodził się na podpisanie żadnej listy deportacyjnej i wybrał samobójstwo.

Spadek zainteresowania dziejami getta łódzkiego niektórzy badacze upatrują m.in. w odkryciu w ruinach getta warszawskiego kolejnej części podziemnego Archiwum Ringelbluma, a co za tym idzie, wysunięcie na pierwszy plan badań nad gettem warszawskim i bohaterskim powstaniem, co „wydawało się w tamtym czasie tematem zarówno ciekawym, jak i najbardziej zgodnym z ówczesnymi tezami propagandowymi, dlatego już od samego początku istnienia CŻKH publikacje mu poświęcone stanowiły widoczną część wydawnictw Komisji” ${ }^{17}$. Ale to nie jedyny powód. Z pewnością przyczyniło się do tego także przeniesienie CŻKH do odbudowanego gmachu dawnej Biblioteki Judaistycznej w Warszawie, jak również zmiana sytuacji politycznej w Polsce ${ }^{18}$.

Zdecydowaną odmianę przyniosły lata sześćdziesiąte. Z jednej strony to czas, kiedy w kraju narasta fala antysemityzmu, której kulminacją stanie się rok $1968 \mathrm{i}$ tzw. wydarzenia marcowe. Z drugiej zaś nastąpił widoczny wzrost liczby publikacji o getcie łódzkim. W stosunku do lat wcześniejszych uległa ona potrojeniu. $Z$ początku lat sześćdziesiątych pochodzą dzienniki napisane w getcie tj. Pamiętnik z getta łódzkiego ${ }^{19}$ Jakuba Poznańskiego wydany nakładem Wydawnictwa Literackiego oraz Dziennik Dawida Sierakowiaka wydany przez Iskry, niestety nie w pełnym wydaniu. W języku polskim dostępne są jedynie dwa pierwsze zeszyty obejmujące okres dwóch lat życia w getcie. Pełna jego edycja od 1996 roku dostępna jest w języku angielskim. Z przedmowy do angielskiego wydania książki dowiadujemy się, że Lucjan Dobroszycki dążył do wydania drukiem wszystkich pięciu zeszytów. Książ-

${ }^{17}$ J. Walicki, Polityka historyczna a nauka. Dzieje badań materiałów archiwalnych getta łódzkiego i jego Kroniki do roku 1968 [w:] Kronika getta łódzkiego, t. 5, Suplement, Łódź 2009, s. 254. Por. N. Aleksiun, Polish historiography of the Holocaust - between silence and public debate, German History 2004, vol. 22, no. 3.

${ }^{18}$ N. Aleksiun, Polish historiography of the Holocaust: between silence and public debate, German History 2005, vol. 22, nr 3, s. 419.

${ }^{19}$ Na temat edycji pamiętnika J. Poznańskiego z lat 1960 r. i 2002 r., zob.: M. Rzadkowolska, Edycja Pamiętnika z getta łódzkiego Jakuba Poznańskiego w Wydawnictwie Łódzkim [w:] Przestrzeń informacyjna ksiażki, red. J. Konieczna, Łódź 2009, s. 257-261. 
ka była już prawie gotowa do publikacji, kiedy starania L. Dobroszyckiego zostały zablokowane zarówno przez ówczesne władze, które coraz niechętniej widziały wydawanie wszelkich publikacji poświęconych tematyce żydowskiej, jak i przez narastający w kraju antysemityzm ${ }^{20}$. W rezultacie Dziennik Sierakowiaka został wycofany z planu wydawniczego. Dzięki staraniom Konrada Turowskiego, dziennikarza, który nie ustawał w zabiegach, by zapiski Dawida Sierakowiaka mogły ujrzeć światło dzienne, pod koniec lat dziewięćdziesiątych książka wreszcie trafiła do rąk angielskojęzycznych czytelników. Wspomniane zeszyty, które nie zostały włączone do wydania z roku 1960, polski czytelnik może odnaleźć na łamach czasopisma „Folks-Sztyme”, które drukowało je w odcinkach w 1972 roku. Niestety wszystko wskazuje na to, że na pełne polskie wydanie tego dziennika przyjdzie nam jeszcze poczekać.

Szczególne miejsce w badaniach nad dziejami getta łódzkiego, a w szerszym kontekście nad dziejami Holocaustu w Polsce, zajmuje publikacja Kroniki getta łódzkiego. Jak podkreślają jej redaktorzy, Kronika zdecydowanie wyróżnia się spośród wielu dokumentów powstałych w czasie Zagłady, jest „źródłem bez precedensu”.

Kronika - jeden z najważniejszych dokumentów w historii getta, powstawała w Wydziale Archiwum Przełożonego Starszeństwa Żydów. Archiwum mieściło się najpierw przy ul. Miodowej 4, potem przeniesione zostało wraz ze wszystkimi komórkami Wydziałów Ewidencji Ludności na pl. Kościelny 4 . Archiwum znajdowało się $\mathrm{w}$ wydzielonym pokoju, do którego prowadziło odrębne wejście. $\mathrm{O}$ istnieniu archiwum wiedział niemiecki zarząd getta, mimo to jego działalność nie mogła „rzucać się” władzom niemieckim zbytnio w oczy. Pracownicy archiwum mieli pełnomocnictwo Rumkowskiego na zbieranie materiałów we wszystkich organach administracji żydowskiej. Zespół pracowników liczył 10-15 osób. W jego skład wchodzili Żydzi polscy i wsiedleni do getta łódzkiego Żydzi z Czechosłowacji. Pierwszym kierownikiem archiwum był Stanisław Cukier-Cerski, a od lutego 1943 roku dr Oskar Singer. Personel Archiwum tworzyli literaci, publicyści, filozofowie. Pracownicy otrzymywali dodatkowe przydziały żywności, podobnie zresztą jak pozostali uprzywilejowani pracownicy administracji żydowskiej. Większość pracowników archiwum została deportowana do Oświęcimia w czasie ostatecznej likwidacji getta w sierpniu 1944 roku i tam zgładzona. Pierwszy numer Kroniki ukazał się 12 stycznia 1941 roku. Do

${ }^{20}$ One life lost [w:] The diary of David Sierakowiak: five notebooks from the Lodz ghetto, Dawid Sierakowiak, ed. Alan Adelson, London 1996, s. 6. 
1 września 1942 roku Kronika pisana była w języku polskim pod tytułem Biuletyn Kroniki Codziennej, a od września 1942 roku do 30 lipca 1944 roku ukazywała się w języku niemieckim jako Tageschronik.

Kronika w języku polskim pisana była niemal codziennie, choć w niektórych okresach biuletyny obejmowały opisy kilkudniowe, a nawet dwutygodniowe lub miesięczne. Każde wydarzenie opisywane jest pod właściwą datą. Natomiast biuletyny Tageschronik były już ściśle codzienne: jeden numer biuletynu odpowiadał jednemu dniowi.

Poszczególne biuletyny omawiają aktualności dnia. Do stałych rubryk należą m.in. stan pogody, zgony i urodzenia $\mathrm{w}$ getcie, postrzelenia przy drutach okalających getto, zamachy samobójcze, przydziały żywnościowe, ceny na rynku pokątnym, działalność Przełożonego Starszeństwa Żydów i jego administracji, rozwój zakładów pracy, stan sanitarny i zdrowotność w getcie, obyczajowość i życie kulturalne, wysiedlenia do getta i deportacje. Wydarzenia opisane w kronice kończą się na ogół przy drutach wokół getta.

Kronika zachowała się niemal w całości. Stało się to w dużej mierze za sprawą Nachamana Zonabenda, którego komando miało zająć się porządkowaniem terenu getta po jego likwidacji. Spora część materiałów dotyczących getta pozostała w opuszczonych pomieszczeniach dawnego Wydziału Archiwum. Zdając sobie sprawę $\mathrm{z}$ wagi tych materiałów, Zonabend podjął wszelkie starania, by je zabezpieczyć. Do momentu wyzwolenia miasta przechował je w studni mieszczącej się przy pl. Kościelnym. Kilkanaście dni później wszystkie zgromadzone dokumenty trafiły do jego mieszkania.

W 1945 roku Zonabend przekazał działającej wówczas w Łodzi CŻKH część uratowanych przez siebie materiałów. Od tej pory wszelkie prace porządkowe oraz redakcyjne nad tekstem Kroniki stały się jednym z priorytetów CŻKH. Potwierdza to sprawozdanie: „opracowanie materiałów łódzkich zajmie sporo czasu, gdyż jesteśmy w posiadaniu wszystkich papierów Judenratu z jego wszystkimi placówkami oraz olbrzymich ilości rękopisów niemieckich władz gettowych i konieczne jest zaangażowanie dodatkowych sił pomocniczych" ${ }^{21}$. Z pierwotnych planów przygotowania materiałów źródłowych nic nie wyszło. Jak podaje dalej badacz dziejów getta J. Walicki „mimo tak unikalnego zasobu źródeł znajdujących się w dyspozycji CŻKH tematyka getta łódzkiego znalazła się na marginesie ukazujących się wówczas w Polsce publikacji o Zagładzie"22.

${ }^{21}$ J. Walicki, Polityka historyczna..., s. 250. Por. N. Zonabend, The truth about the saving of the Lodz Ghetto archive, Stockholm 1991; The documents of the Lodz ghetto: an inventory of the Nachman Zonabend Collection: (record group no. 241), red. M. Web, New York 1988.

${ }^{22}$ Tamże, s. 253. 
W latach sześćdziesiątych XX wieku do prac nad Kroniką przystąpiła Danuta Dąbrowska, która jako jedna z pierwszych historyków podjęła szeroko zakrojone badania nad dziejami getta łódzkiego. Wyniki swoich badań publikowała głównie na łamach Biuletynu ŻIH. Wkrótce dołączył do niej Lucjan Dobroszycki. Efektem ich pracy było wydanie dwóch pierwszych tomów Kroniki. W początkowym okresie nic nie zapowiadało trudności, które na skutek wydarzeń politycznch miały niebawem nastąpić. Dyrektor Wydawnictwa Łódzkiego Aleksander Postołow poparł inicjatywę opublikowania Kroniki, czego wyrazem była podpisana umowa na jej wydanie w 1963 roku. W tym samym roku nastąpił zwrot w polityce państwa, w rezultacie czego wszelkie badania nad Zagładą poświęcone tematyce żydowskiej znajdowały coraz mniej zrozumienia. Niestety prace podjęte nad kolejnymi tomami zostały przerwane, zaś gotowe do wydania kolejne tomy Kroniki, które miały ukazać w 1968 roku zostały usunięte z planu wydawniczego, a materiały zniszczone. Niedługo potem redaktorzy Kroniki wyjechali z Polski.

W 1984 roku w Stanach Zjednoczonych ukazało się angielskie wydanie Kroniki. Niestety było w dużym stopniu okrojone. Po prawie czterdziestu latach od pierwszej edycji Kroniki staraniem polskiego zespołu badawczego, ukazało się jej pełne wydanie, które trafiło do rąk czytelników w czasie obchodów 65. rocznicy likwidacji getta łódzkiego. Dwa lata wcześniej ukazała się niemiecka edycja Kroniki. Każdy jej rok został wydany w osobnym tomie, opatrzony bogatym aparatem naukowym.

Przedstawiając literaturę dotyczącą Litzmannstadt Getto, nie można pominąć monumentalnej, trzytomowej powieści Chavy Rosenfarb w języku jidysz o zagładzie społeczności żydowskiej w jej rodzinnym mieście Łodzi, zatytułowanej Der boym fun lebn (Drzewo życia). Powieść, którą krytyka niemal natychmiast okrzyknęła arcydziełem, przyniosła pisarce liczne prestiżowe nagrody, w tym jedną z najważniejszych - literacką nagrodę Manger’a (1972).

Der boym fun lebn przetłumaczono na język hebrajski oraz angielski. Niestety wydawca skrócił pierwsze angielskie wydanie powieści. Obawiał się finansowego niepowodzenia oraz braku zainteresowania angielskich czytelników, dla których nazwisko Chavy Rosenfarb było nieznane. W rezultacie ukazało się jednotomowe (!) wydanie w 1985 roku. Dopiero dwadzieścia lat później Chava Rosenfarb, we współpracy ze swoją córką Goldie Morgentaler, przetłumaczyła powieść w całości. Owocem tej współpracy stało się pełne trzytomowe wydanie, które trafiło do rąk angielskich czytelników w 2004 roku. 
Drzewo życia to opowieść o 10 mieszkańcach Łodzi, których historia zaczyna się tuż przed wybuchem II wojny światowej, a następnie rozgrywa $\mathrm{w}$ granicach getta łódzkiego. Każdy $\mathrm{z}$ bohaterów powieści pochodzi z innego środowiska. Dzięki temu zabiegowi Der boym fun lebn przedstawia przekrój całej społeczności getta. Autorka dokładnie opisuje codzienne życie jego mieszkańców, zmaganie się z głodem, rzeczywistością getta, a także ich zagładę. Oprócz bohaterów fikcyjnych, spotykamy też postacie, które swoje pierwowzory miały w rzeczywistości, takie jak Simcha Szajewicz czy Chaim Rumkowski. Losy bohaterów urywają się w momencie likwidacji getta. Rosenfarb celowo nie kontynuuje ich dalszego losu.

Od lat dziewięćdziesiątych odnotowuje się zdecydowany wzrost publikacji o getcie łódzkim w piśmiennictwie dotyczącym Holocaustu. Począwszy od połowy lat czterdziestych, kiedy zaczęły powstawać pierwsze teksty o zagładzie łódzkich Żydów, liczba ta stale rośnie. Na podstawie zgromadzonego materiału wynika, że w latach 1990-1999 na temat getta łódzkiego ogółem ukazało się około 223 publikacji natomiast w następnej dekadzie liczba ta wzrosła do około 452, co świadczy o stałym i rosnącym zainteresowaniu tematem.

Wzrost zainteresowania dokonał się za sprawą kilku czynników, które przyczyniły się do tego, że o getcie zaczęto pisać więcej i częściej. Do najważniejszych publikacji należy monografia getta łódzkiego autorstwa Icchaka Rubina Żydzi w Łodzi pod niemiecką okupacja 1939-1945, która swoją premierę miała w Londynie. Książka już na początku została uznana za dość kontrowersyjną głównie ze względu na stanowisko autora wobec osoby Przełożonego Starszeństwa Żydów w getcie Ch. M. Rumkowskiego. Książka Rubina zasługuje na uwagę przede wszystkim ze względu na ilość wykorzystanych źródeł, do których autor dotarł, pracując nad książką. Novum stanowi wykorzystanie źródeł w różnych językach, w tym w języku jidysz i hebrajskim. Rubin polemizuje z dziełem Trunka, które zostało opublikowane w 1962 roku w języku jidysz. Zarzuca mu zbyt krytyczną ocenę Rumkowskiego i jego polityki. Jego zdaniem „Rumkowski jest w zasadzie postacią heroiczną dążącą do uratowania tylu Żydów, ilu mógł uratować i prawie udałoby mu się uratować 70 tys. Żydów, gdyby nie klęska Armii Czerwonej, która nie zdołała pokonać ostatnich 65 mil latem 1944, by dotrzeć do Łodzi”. Jego pozytywna ocena Rumkowskiego oraz rad żydowskich w czasie Holocaustu zszokowała i skonsternowała środowisko akademickie. W przeciwieństwie do niego Trunk zdecydowanie odcina się od takiej postawy, wyraźnie rozróżniając kolaborację od wymuszonej współpracy. W 2006 roku dzieło Trunka doczekało się tłumaczenia na język angielski, 
dzięki czemu grono jej czytelników nie ograniczało się już tylko do wąskiego kręgu specjalistów operujących językiem jidysz.

Pod koniec lat osiemdziesiątych do księgarni trafił zbeletryzowany zbiór opowiadań Arnolda Mostowicza poświęcony gettu łódzkiemu pod tytułem Żólta gwiazda, czerwony krzyż. Autor zawarł w nim obraz getta, codzienne zmaganie się jego mieszkańców z głodem, ale także przedstawił sytuację wsiedlonych do getta Żydów z Europy Zachodniej oraz ich nieumiejętność odnalezienia się w rzeczywistości getta. Mostowicz w getcie pracował w szpitalu chorób zakaźnych, w pogotowiu ratunkowym oraz jako lekarz sanitarny getta. Jego wspomnienia jako jedyne spośród wszystkich powstałych w getcie oraz tych pisanych już w okresie powojennym zawierają opis obozu cygańskiego utworzonego wewnątrz getta, którego granice przekroczył jako lekarz. Tę dramatyczną relację zamieścił w rozdziale pod tytułem Raport z obozu cygańskiego.

W tym samym czasie na zachodzie ukazywały się wspomnienia oraz opracowania dotyczące getta. Robert Skloot zebrał i wydał w książce zatytułowanej The theatre of the Holocaust: four plays sztuki teatralne powstałe na bazie materiałów dokumentujących Zagładę. Dwie spośród nich Resort 76 i Słomiany tron przedstawiają życie Żydów w getcie pod surowymi rządami Chaima Rumkowskiego, któremu Niemcy nadali pewne administracyjne uprawnienia. Sztuka Resort 76 napisana przez Shimona Wincelberga na podstawie noweli Rachmila Bryksa A cat in the ghetto to czarna komedia, której akcja toczy się w Łodzi, w zaniedbanej, upadającej fabryce, w której przerabia się odpady tekstylne. Dokładnie opisuje wynędzniałych robotników, którzy tam żyją i pracują. Odzwierciedlają oni wszystkie warstwy społeczne, które znajdowały się w getcie łódzkim - począwszy od drobnego złodziejaszka, po historię nastoletniego chłopca o imieniu Beryl i jego nauczyciela.

Od połowy lat osiemdziesiątych tematyka getta łódzkiego stała się przedmiotem krajowych oraz międzynarodowych seminariów i konferencji. W 1984 roku Okręgowa Komisja Badania Zbrodni Hitlerowskich w Łodzi zorganizowała konferencję pod nazwą Getto w Łodzi 1940-1944, podczas której poruszono zagadnienia dotyczące administracji i policji żydowskiej, organizacji getta, form eksterminacji Żydów zamkniętych w getcie łódzkim, jak również sprawę odpowiedzialności za zbrodnie popełnione na Żydach. Na tym etapie dzieje getta łódzkiego analizowano i omawiano w wąskim gronie specjalistów historyków. Co ciekawe, kolejna konferencja odbyła się dziesięć lat później. Sześćdziesiąta rocznica likwidacji getta łódzkiego dała asumpt do zorganizowania międzynarodowej konferencji pod hasłem Fenomen getta łódzkiego (2004), która przyciągnęła dziesiątki osób, w tym naukowców, 
przewodników, dziennikarzy, studentów jak również mieszkańców Łodzi zainteresowanych poznaniem dziejów żydowskiego getta. Rok wcześniej Uniwersytet Łódzki zorganizował konferencję Pamięć Shoah - współczesne reprezentacje (2003), podczas której zagadnienia z historii getta łódzkiego stały się tematem poszczególnych paneli. Od tego czasu sukcesywnie różne aspekty $\mathrm{z}$ dziejów getta łódzkiego omawia się na kolejnych seminariach.

Bardzo ważny w piśmiennictwie o zagładzie łódzkich Żydów jest rok 2004. W sierpniu tego roku przypadła sześćdziesiąta rocznica likwidacji getta łódzkiego, której towarzyszyły wystawy, wykłady, koncerty, spotkania z ocalałymi. Specjalnie na to wydarzenie przygotowano kilka publikacji dotyczących getta łódzkiego. Nie można też pominąć tego, co działo się na rynku wydawniczym przed 2004 rokiem, a co wiązało się ze stopniowym przywracaniem pamięci o getcie.

Ogromne zasługi dla popularyzacji wiedzy o getcie położył Julian Baranowski, historyk, archiwista, którego wkład w badania nad gettem łódzkim jest nie do przecenienia. Baranowski o getcie zaczął pisać już od połowy lat osiemdziesiątych, jest autorem kilku ważnych opracowań, do których należą Łódzkie getto 1940-1944 = The Łódź ghetto 1940-1944: vademecum, które doczekało się kilku wydań i jest podstawowym źródłem wiedzy o getcie, Żydzi wiedeńscy w getcie łódzkim 1941-1944 = Wiener Juden In Getto Lodz 1941-1944 oraz jednej jak dotąd książki o obozie cygańskim w getcie łódzkim Zigeunerlager in Litzmannstadt 1941-1942 = The Gypsy Camp in Łódź 1941-1942 = Obóz cygański w Łodzi 1941-1942. Spośród licznych publikacji o getcie nie można pominąć prac Marka Budziarka, Joanny Podolskiej, wówczas dziennikarki łódzkiego oddziału Gazety Wyborczej, Pawła Spodenkiewicza i Krzysztofa Woźniaka, którzy na łamach lokalnej prasy przypominali o dziejach getta, jego mieszkańcach i ich tragicznym losie.

Od tego czasu pojawiają się kolejne wspomnienia spisane już po wojnie Gwizd życia Eliezera i Racheli Grynfeld, Wstrząsnąć filarami świątyni Ruth Eldar czy A droga wiodła przez Łódź zawierająca wspomnienia Tosi i Aleksandra Klugmanów. To oczywiście nie wszystkie publikacje, jakie zaczęły się ukazywać. Niektóre z dotąd niepublikowanych materiałów o getcie we fragmentach ukazywały się na łamach czasopism bądź w pracach zbiorowych, tak było na przykład z przywoływaną już wcześniej sztuką teatralną Słomiany tron, która od 1982 roku funkcjonowała tylko w języku angielskim, ukazała się w polskim przekładzie na łamach Tygla Kultury (2004). Wspomnienia Szlomo Franka zatytułowane Togbuch fun Lodżer geto (1958) weszły w skład relacji z czasów Zagłady do tomu Chroniques du désastre. Témoignages sur la Shoah dans les ghettos polonais w tłumaczeniu Nathana 
Weinstocka (1999). Ogromne zainteresowanie wzbudziła publikacja wspomnień Estery Daum ${ }^{23}$, która w getcie pracowała jako sekretarka Chaima Rumkowskiego w opracowaniu Elżbiety Cherezińskiej. Na uwagę zasługuje także Notatnik Szmula Rozensztajna, pełniącego w getcie funkcję osobistego sekretarza Rumkowskiego ${ }^{24}$. Publikacja tym cenniejsza, że dotąd korzystać z niej mogli tylko ci badacze, którzy znali język jidysz.

\section{Zapomniane księgi pamięci}

Żydowskie księgi pamięci tzw. yizkor bicher poświęcone zgładzonym w czasie II wojny światowej żydowskim społecznościom miast i miasteczek Europy Wschodniej zajmują szczególnie miejsce w literaturze Holocaustu. Największa ich liczba powstała w okresie powojennym, $\mathrm{z}$ inicjatywy poszczególnych ziomkostw rozproszonych w krajach diaspory i stanowiła reakcję ocalałych na doświadczenie Zagłady. Dążeniem autorów ksiąg pamięci, wśród których w większości znajdowali się pisarze-amatorzy, znaczniej rzadziej zawodowi historycy, było „wzniesienie pomnika zamordowanym”, odtworzenie życia i zagłady unicestwionych społeczności oraz przedstawienie dziejów poszczególnych gmin żydowskich ${ }^{25}$. We wszystkich księgach pamięci na pierwsze miejsce wysuwają się teksty poświęcone Zagładzie. Zdecydowana większość wydanych po wojnie ksiąg ukazała się w języku jidysz. Jeśli weźmiemy pod uwagę fakt, że przed wybuchem wojny co trzeci mieszkaniec Warszawy i co piąty Nowego Jorku posługiwał się językiem jidysz, to decyzja, by publikować księgi właśnie w tym języku zyskuje wymiar symboliczny.

Jednym z pierwszych dokumentów poświęconych Litzmannstadt Getto $\mathrm{w}$ języku żydowskim jest księga pamięci Lodzer izker-buch wydana w 1943 roku w Nowym Jorku. Żydowskie księgi pamięci są „najbardziej charakterystycznym i unikalnym zjawiskiem $\mathrm{w}$ piśmiennictwie powstałym w wyniku doświadczenia Zagłady"26. Intencją autorów, którzy je pisali, było przede wszystkim upamiętnienie społeczności żydowskiej zgładzonej

${ }^{23}$ E. Cherezińska, Byłam sekretarką Rumkowskiego: dzienniki Etki Daum, Poznań 2008.

${ }^{24}$ J. Podolska, Szmul i Chaim. Książka o Chaimie Mordechaju Rumkowskim. Zagłada Żydów: studia i materiały 2009, nr 5, s. 542-547. W 2011 r. ukazały się w Wydawnictwie Łódzkim wiersze i poematy poety z getta łódzkiego Jeszajahu Szpigla przetłumaczone z jidysz przez Małgorzatę Zarembę Przeżyliśmy: proza Jeszajahu Szpigla z getta łódzkiego, Łódź 2011.

${ }_{25}$ M. Adamczyk-Grabowska, A. Kopciowski, Zamiast macewy. Żydowskie księgi pamięci [w:] Nastęstwa zagłady Żydów. Polska 1944-2010, praca zbiorowa pod red. F. Tycha, M. Adamczyk-Grabowskiej, Lublin 2011, s. 442.

${ }^{26}$ Tamże, s. 441. 
w czasie II wojny światowej. Z jednej strony - zdaniem Adama Kopciowskiego - księgi pamięci są kroniką, syntezą dziejów gmin żydowskich, której celem jest ocalenie od zapomnienia ich tragicznej historii i przekazanie jej potomnym, z drugiej - pomnikiem pamięci i hołdem złożonym ofiarom Zagłady. Eksterminacja Żydów zdeterminowała temat powstających w okresie powojennym ksiąg, wpłynęła także na ich układ ${ }^{27}$.

Żydowskiej Łodzi, jej mieszkańcom i historii miasta poświęconych jest aż sześć ksiąg pamięci. Pierwsza zdążyła ukazać się jeszcze w czasie wojny, kiedy w Łodzi wciąż istniało getto. Dwie kolejne Churbn Lodz, 6 jor naci-gehenem (aut. Israel Tabaksblat) oraz Kehilat Lodz, ir wa-em be Israel ukazały się rok po roku. Niespełna dziesięć lat po ich publikacji, powstała kolejna księga Lodż un ire Jidn (1956) napisana przez A. Tenenbauma. W 1974 roku ukazała się Jidisz Lodż, zaś ostatnia księga Pinkes Lodz: a izker-buch fun der sztot Tojre u-gdule trzydzieści lat później, w 2005 roku.

Układ ksiąg do pewnego stopnia jest podobny. Księgę z 1943 roku otwiera opis miasta sprzed wojny ${ }^{28}$. Na czterdzieści cztery rozdziały jedynie dwanaście poświęconych jest wizerunkowi miasta z tego okresu, czego potwierdzeniem są m.in.: Łódź nasze miasto rodzinne ${ }^{29}$; Żydowska Łódź; Żydowski rabin; Szmuel Hirszenberg; Izrael Lichensztajn; Łódzko-żydowskie towarzystwa. Pozostałych dwadzieścia pięć rozdziałów odnosi się do aktualnych wydarzeń, czyli do spraw getta oraz zagłady łódzkich Żydów (Herszele - trubadur; Pierwsze pozdrowienie z getta; W Litzmannstadt etc.). Księga została wydana przez Zjednoczony Komitet Pomocy dla Miasta Łodzi w Nowym Jorku. Spośród wielu jej autorów wymienić należy m.in. Jakuba Szackiego (Gustaw Ajzer), Josefa Okrutnego (zgony i samobójstwa), Mojżesza Brodersona (faszystowski humor), Icchaka Jonasowicza (jakie było „niemieckie” miasto). Otwiera ją dedykacja poświęcona wszystkim „siostrom i braciom z naszego rodzinnego miasta Łodzi, którzy zginęli męczeńską śmiercią z rąk hitlerowskich bestii i ich pomocników"30. Co ciekawe prace nad jej powstaniem trwały prawie trzy lata (niektóre teksty datowane są na

27 Układ ksiąg: Cz. 1 - zawiera najczęściej zmitologizowaną historię gminy i jej rozwoju, teksty przedstawiające życie społeczne, polityczne, kulturalne, religijne, biogramy najwybitniejszych postaci oraz opisy topograficzne. Cz. 2 - to opisy Zagłady, często w formie relacji jej bezpośrednich świadków. Cz. 3 - przedstawione są powojenne powroty do rodzinnych miejscowości i działalność ziomkostw. Księgi kończą zwykle listy osób zamordowanych w czasie Zagłady oraz nekrologi. Zob.: A. Kopciowski, Księgi pamięci gmin żydowskich: bibliografia = Jewish memorial books: a bibliography, Lublin 2008, s. 8.

${ }^{28}$ Dokładny spis treści Księgi zawiera załącznik nr 1 do niniejszego artykułu.

${ }^{29}$ Wszystkie tłumaczenia z jidysz moje.

${ }^{30}$ Lodżer izker-buch, New York 1943, s. 3. 
1941 roku jak np. tekst Mojżesza Brodersona). Redaktorom przyświecały dwa cele. Po pierwsze „wyrazić miłość do rodzinnej Łodzi poprzez zanotowanie faktów i dat, które są niezbędne dla przyszłych historyków oraz by postawić niewielki pomnik, który z taką nienawiścią został zburzony rękami zbrodniarzy”, a po drugie, by „za pośrednictwem tej księgi zorganizować pomoc materialną dla łódzkich Żydów i Żydów w Łodzi, kiedy nadejdzie upragnione wyzwolenie" 31 .

Inaczej jest $z$ wydaną trzy lata później księgą pamięci autorstwa I. Tabaksblata $^{32}$. Autor, były mieszkaniec getta łódzkiego, nie wprowadza czytelników w historię przedwojennej Łodzi. Jego historia zaczyna się od momentu wejścia Niemców do Łodzi i zajęcia miasta, po stopniowe przekształcanie życia Żydów w piekło, by w dalszej części skoncentrować się na możliwie wiernym odtworzeniu życia w zamkniętej dzielnicy, jaką było getto w czasie wojny. Układ książki ${ }^{33}$ zdecydowanie różni się od poprzedniej. Nie ma klasycznego rozgraniczenia historii Żydów na przedwojenną i w czasie Zagłady. Omawiana księga stanowi, zdaniem redaktorów, pierwszą pracę dokumentalną o getcie łódzkim. Autor, który spędził w nim cztery lata, widział je we wszystkich barwach oraz dostrzegał wszelkie niuanse, zdecydowanie odsuwa swoje osobiste wspomnienia, koncentrując się na zapisie doświadczenia „najciemniejszych lat życia w piekle” całej społeczności żydowskiej ${ }^{34}$. Książka powstała na przestrzeni lat 1944/1945, ale pierwsze zapiski pochodzą z ostatnich kilku miesięcy sprzed likwidacji getta. Tabaksblat oskarża

31 Tamże, s. 9.

32 Izrael Tabaksblat (1891-?), pochodził z biednej żydowskiej rodziny. Po ukończeniu szkoły średniej pracował jako robotnik w jednej z łódzkich fabryk tekstylnych dochodząc do stopnia majstra (był jednym żydowskim majstrem w fabryce pluszu Zakładu Akcyjnego "Zawiercie”). Od wczesnych lat był aktywny w środowisku syjonistycznym. Już jako uczeń liceum kierował organizacją młodzieżową. Od 1906 r. związany z organizacją Poalej Syjon. Zaangażowany także w działalność dziennikarską. Publikował artykuły na łamach prasy żydowskiej i polskiej poświęcone problematyce ekonomicznej. W latach II wojny światowej razem z rodziną znalazł się w getcie łódzkim. Włączył się w działalność konspiracyjną w getcie. Deportowany z getta do obozu Auschwitz-Birkenau w sierpniu 1944 r., gdzie stracił żonę i syna. Drugi syn stracił życie podczas walk partyzanckich w rejonie zagłębiowskim. Z Auschwitz-Birkenau trafił do kolejnych obozów. Po wyzwoleniu przez wojska alianckie 10.05.1945 r., w stanie skrajnego wycieńczenia przez pewien czas przebywał w szpitalu. Po powrocie do Łodzi rozpoczął współpracę z gazetą żydowską Dos Naje Lebn. Zob.: Isroel Tabaksblat, Churbn Lodź, 6 jor naci-gehenem, Buenos Ajres 1946, s. 12.

33 Książka Izraela Tabaksblata składa się z ośmiu zasadniczych rozdziałów: 1. Do czytelnika, 2. Zamiast wstępu, 3. Przedsionek piekła, 4. Żydowska autonomia, 5. Likwidacja prowincji, 6. A chejzer szture-wint iber geto, 7. Likwidacja getta, 8. Auschwitz, 9. K.C. Obozy.

34 Onsztot a hakdome [w:] Isroel Tabaksblat, Churbn Lodź, 6 jor naci-gehenem, Buenos Ajres 1946, s. 12 . 
nie tylko Niemców o wymordowanie Żydów, ale równie krytycznie wyraża się o żydowskich zdrajcach, zaliczając do nich Judenrat oraz policję żydowską, przedstawicieli świata przestępczego oraz tych wszystkich, którzy osobiście przyczynili się do śmierci niewinnych Żydów, będąc na „usługach nazistowskich katów". Choć książka nie wyczerpuje tematu getta do końca, to jednak jej redaktorzy żywili nadzieję, iż przysłuży się kiedyś badaczom. Niestety ich nadzieje nie doczekały się dotąd realizacji.

Wydana w 1974 roku przez Łódzki Ośrodek Melbourne księga Jidisz Lodz została podzielona na trzy części wyraźnie rozgraniczające opisywane okre$\mathrm{sy}^{35}$. W pierwszej części nazwanej Łódź $w$ okresie międzywojennym dominują opisy poświęcone łódzkim ważnym osobistościom życia kulturalnego oraz społecznego (znajdują się tu informacje dotyczące malarzy, pisarzy, lekarzy, dziennikarzy, z czego większość opisów przypomina szerzej opracowane hasła encyklopedyczne). Część druga Zagłada Łodzi jest objętościowo przeważająca. Zawarte w niej opisy prowadzą czytelnika od ogólnej historii getta łódzkiego, poprzez konkretne sytuacje jak „Dzieci w getcie łódzkim”, „Życie kulturalne w getcie” czy „Słuchacze radia w getcie”, zaś wieńczą wiersze oraz osobiste wspomnienia. Z kolei część trzecia Łódź po wojnie traktuje już o okresie powojennym i jest o tyle ciekawa, że nie pojawiała się dotąd w żadnej ze wcześniejszych ksiąg poświęconych Łodzi.

Obraz żydowskiej Łodzi otwiera sześciotomową serię ksiąg pamięci Pinkas ha- Kehilot = Encyclopedia of Jewish Communities opracowaną przez Instytut Yad Vashem w Izraelu. Tom I zatytułowany The communities of Lodz and its region zaczyna się od opisu zgładzonej w czasie wojny społeczności żydowskiej w Łodzi oraz 116 miasteczek całego regionu.

Dążeniem autorów projektu było wystawienie pomnika Żydom europejskim zgładzonym w czasie II wojny światowej. Opisy zawartych w księdze miast i miasteczek województwa łódzkiego mają postać haseł encyklopedycznych. Ich rozpiętość zależy od informacji, jakimi dysponowali autorzy ${ }^{36}$. Najwięcej miejsca poświęcono tym miastom, w których Żydzi odegrali znaczącą rolę w życiu ekonomicznym, kulturalnym, politycznym itd. Żydowska Łódź w omawianej encyklopedii liczy czterdzieści strony. Uwzględniano te

\footnotetext{
${ }_{35}$ Zob. załącznik nr 2 do niniejszego artykułu.

${ }^{36} \mathrm{~W}$ oparciu o dostępne materiały uwzględniono np. miasteczko Andrzejów, gdzie liczba Żydów wynosiła 100, czy Woli Kosztoporskiej gdzie z kolei mieszkało zaledwie 60 Żydów. Zaś gmina Opatów z liczbą żydowskich mieszkańców wynoszącą w 1921 r. 186 wobec braku jakichkolwiek źródeł została pominięta. Introduction [w:] Pinkes ha-Kehillot: encyclopedia of Jewish communities. Poland. Vol. 1, The communities of Lodz and its region, ed. D. Dąbrowska, A. Wein, Jerusalem 1976, s. 8.
} 
społeczności, w których liczba Żydów wynosiła kilkaset osób. Szczególny nacisk położono jednak na te miasteczka żydowskie, o których dotąd niewiele napisano, bądź gdzie liczba Żydów nie przekraczała kilkudziesięciu mieszkańców, w tym przypadku kierując się obawą utraty pamięci o nich. Opracowując poszczególne hasła, autorzy encyklopedii oddali pierwszeństwo wydarzeniom, które rozegrały się w czasie Zagłady ${ }^{37}$.

Decyzja o poświęceniu pierwszego tomu serii właśnie Łodzi i regionowi łódzkiemu nie była zdaniem autorów przypadkowa. Do 1939 roku tereny te zamieszkiwała prawie 1/7 polskich Żydów. Łódź zwana potocznie „polskim Manchesterem" stanowiła w tym czasie drugie po Warszawie największe skupisko mniejszości żydowskiej.

W ciągu ostatnich kilkunastu lat wiele napisano na temat getta łódzkiego. Niektóre zagadnienia doczekały się obszernych studiów, jedne mają charakter przyczynkowy, inne wciąż czekają na opracowanie. Zadziwiające, że spośród tak bogatej literatury przedmiotu, w badaniach nad dziejami getta łódzkiego tak rzadko wykorzystywane są właśnie wspomniane księgi pamięci. Jest to przecież obszerny materiał dotyczący Łodzi, który stanowi cenne źródło dla historyków, badaczy kultury, antropologów, regionalistów oraz pasjonatów historii miasta. Dużo większym powodzeniem cieszą się wspomnienia $\mathrm{z}$ okresu wojny pisane w języku jidysz, które stopniowo zaczynają być tłumaczone na język polski (warto wymienić zainicjowaną przez Centrum Badań Żydowskich serię Biblioteka Świadectw Zagłady, w ramach której ukazał się dziennik Szmula Rozensztajna w tłumaczeniu Moniki Polit).

Nie ulega wątpliwości, że źródła w języku jidysz dotyczące getta łódzkiego, przez długie lata pomijane i lekceważone ze względu na ich rozproszenie, jak również barierę językową, wciąż czekają na odkrycie i przybliżenie ich szerszej publiczności.

\section{Projekt bibliografii}

Pomysł utworzenia zbiorczej Bibliografii getta łódzkiego narodził się kilka lat temu jako wynik zainteresowania autorki dziejami Żydów w Łodzi w czasie okupacji hitlerowskiej. Drugim czynnikiem, który przyczynił się do rozpoczęcia prac nad zebraniem rozproszonej w piśmiennictwie polskim i europejskim literatury dotyczącej getta łódzkiego jest intensywny wzrost zainteresowania wśród naukowców, publicystów oraz studentów historią

${ }^{37}$ Y. Arad, Preface [w:] Pinkes ha-Kehillot: encyclopedia of Jewish communities. Poland. Vol. 1, The communities of Lodz and its region, Jerusalem 1976, s. 7. 
Litzmannstadt Getto. Rezultatem badań podejmowanych przez środowiska akademickie są międzynarodowe konferencje ${ }^{38}$, projekty ${ }^{39}$, publikacje naukowe przedstawiające najnowsze osiągnięcia, a także liczne literackie i artystyczne reprezentacje w literaturze i sztuce będące rezultatem badań i studiów nad Zagładą.

Tematyka getta łódzkiego fascynuje od kilkudziesięciu lat badaczy reprezentujących różne dyscypliny naukowe od historii, literaturoznawstwa po takie dyscypliny jak sztuki plastyczne, filmoznawstwo i tym podobne.

W ciągu sześćdziesięciu pięciu lat od likwidacji getta łódzkiego powstało w różnych językach wiele wartościowych prac oraz interesujących materiałów źródłowych. Ci, którzy przeżyli, „przeszli przez łódzkie getto”, spisali swoje wspomnienia $\mathrm{w}$ różnych formach literackich od dzienników po beletrystykę, od opracowań historycznych po sztuki teatralne. Zachowane do naszych czasów wspomnienia, relacje, opracowania zostały napisane po polsku, angielsku, niemiecku, hebrajsku i w jidysz. Wiele z tych wspomnień do dziś jest nieznanych ani nieprzetłumaczonych na język polski. Dodatkowo wiele $\mathrm{z}$ nich wciąż pozostaje poza zasięgiem badaczy ze względu na rozproszenie materiałów w bibliotekach na całym świecie. Dodatkową barierą $\mathrm{w}$ dotarciu do nich jest także nieznajomość języków, w jakich te wspomnienia czy opracowania zostały napisane. Zebranie literatury zarówno naukowej, jak i beletrystycznej, o charakterze informacyjnym i artystycznym, omawiającej dzieje getta łódzkiego we wszystkich dostępnych językach umożliwi zobrazowanie skali poruszanej problematyki przy analizowaniu dziejów getta łódzkiego.

Założeniem Bibliografii, oprócz stworzenia narzędzia wyszukiwawczego do prac badawczych i edukacyjnych, jest przybliżenie najczęściej poruszanych zagadnień przez badaczy, jak również zwrócenie uwagi na te obszary, które wciąż pozostają poza polem zainteresowania historyków Zagłady, getta łódzkiego czy historyków literatury i wymagają dogłębnych studiów i badań. Prawdopodobnie przedstawienie w bibliografii dotychczasowych wyników badań nad gettem łódzkim stanie się podstawą do podjęcia kolejnych prac o charakterze naukowo-badawczym.

Bibliografia getta łódzkiego ma rejestrować wszelkie publikacje, które ukazały się drukiem w piśmiennictwie światowym na przestrzeni lat 1945-2012. Przyjęcie takiej chronologii zobrazuje proces kształtowania się litera-

\footnotetext{
38 „Fenomen getta łódzkiego”: międzynarodowa konferencja naukowa 11-12 października 2004 r.; Seminarium naukowe „Żydzi zachodni w Litzmannstadt Getto”, 26 pażdziernika 2011 r.

${ }^{39}$ Żydzi berlińscy w Litzmannstadt Getto - polsko-niemiecki projekt naukowy realizowany w latach 2009-2010; edycja naukowa Kroniki getta łódzkiego (2009).
} 
tury i piśmiennictwa getta, a także uwzględni publikacje dawne bądź opracowane w językach nieeuropejskich, które nie miały dotąd szansy dotrzeć do szerszego grona odbiorców. Ponadto uwzględnione zostaną nie tylko artykuły naukowe, polemiki, recenzje, materiały konferencyjne, opracowania, monografie czy rozdziały w książkach. Bibliografia wykaże również informacje o konferencjach, filmach czy materiałach edukacyjnych.

Literatura dotycząca historii getta łódzkiego uwzględniająca różne języki jak np. angielski, niemiecki, polski, francuski czy zdecydowanie mniej znane języki jak jidysz i hebrajski, jest bardzo obszerna i zróżnicowana. Planowany projekt ma wypełnić lukę w badaniach bibliograficznych, zebrać i ujawnić rozproszone w świecie informacje dotyczące getta łódzkiego, a w konsekwencji zaprezentować powstałe dotychczas publikacje omawiające historyczne, literackie oraz artystyczne reprezentacje getta łódzkiego.

Zgromadzony w bibliografii materiał zostanie podzielony na kilka działów tematycznych ${ }^{40}$, w obrębie których rekordy zostaną opisane zgodnie z obowiązującymi zasadami opisu bibliograficznego. Ponadto opisy te zostaną zaopatrzone $\mathrm{w}$ adnotacje oraz będą zawierać informacje dotyczące kolejnych wydań, uwzględnią recenzje opublikowane na łamach prasy fachowej oraz informacje o tłumaczeniu publikacji na języki obce.

Uzupełnieniem spisu bibliograficznego będzie indeks autorski oraz wykaz tytułów czasopism występujących w bibliografii wraz ze skrótami. Umożliwi to przyszłemu czytelnikowi szybką i łatwą orientację w przeglądaniu literatury dotyczącej określonego zagadnienia $\mathrm{z}$ historii getta łódzkiego.

Bibliografia, która w założeniu nie będzie ograniczać się do jednego języka, zasięgiem terytorialnym obejmie cały świat, zostanie przygotowana w oparciu o istniejące bibliografie narodowe w szczególności m.in. „Przewodnika Bibliograficznego”, „Bibliografii Zawartości Czasopism”, „Polskiej Bibliografii Literackiej”, „Polskiej Bibliografii Historycznej”. Przeszukane zostaną bibliografie narodowe i katalogi bibliotek narodowych we Francji, Niemczech, Wielkiej Brytanii, Izraelu, USA. Niewątpliwie pomocne przy wyszukiwaniu literatury będą źródła elektroniczne. Najwięcej trudności dostarczy przeszukiwanie prasy w języku jidysz, która nie dość, że jest rozproszona, to nie doczekała się dotąd żadnych zbiorczych indeksów, które ułatwiłyby wyszukiwanie artykułów. Bibliografia uwzględni artykuły, które ukazały się również w prasie codziennej, w tym celu niezbędne będzie przejrzenie całych roczników poszczególnych tytułów czasopism. Dodatkową zaletą zgromadzonego w bibliografii materiału będzie również wyka-

\footnotetext{
${ }^{40}$ Zob. zał. 3 do niniejszego artykułu.
} 
zanie wszelkich materiałów audiowizualnych (w oparciu o zbiory Filmoteki Narodowej oraz PWSTiTV w Łodzi), edukacyjnych, które w sposób bezpośredni dotyczą poszczególnych motywów z historii getta łódzkiego, jak również tych, które w sposób pośredni wiążą się z poruszaną tematyką.

Zdecydowanym walorem przygotowanej bibliografii, który podniesie jej wartość, będą adnotacje, przybliżające publikacje niedostępne, nieistniejące w polskim obiegu naukowym czy nieznane dotąd ze względu na język, w jakim powstały. Natomiast dzięki osobistej weryfikacji dokonanej poprzez kwerendy w bibliotekach zagranicznych, zasobach elektronicznych czy sprowadzaniu niezbędnych materiałów drogą wypożyczalni międzybibliotecznej każdy zamieszczony w bibliografii opis bibliograficzny oraz adnotacje będą dokonane $\mathrm{z}$ autopsji i przyporządkowane do właściwego działu tematycznego na podstawie analizy treściowej.

\section{Zakończenie}

Literatura na temat getta łódzkiego powstała w wielu językach, funkcjonuje też w wielu formach językowej ekspresji jako powieści, opowiadania, sztuki teatralne, wiersze, pamiętniki, dzienniki, ale również jako monografie i opracowania naukowe. Liczba publikacji, które odnoszą się do tego tematu, przekracza ponad tysiąc rekordów. Wydarzenia polityczne, cenzura, emigracja ocalałych jak i naukowców w marcu 1968 roku, edukacja historyczna bez wątpienia wpłynęły na odbiór i świadomość dziejów getta łódzkiego. Z drugiej strony rozwój studiów jidyszystycznych, powstanie na uniwersytetach ośrodków poświęconych studiom żydowskim, nieprzychylny stosunek władz do prowadzenia badań nad Holocaustem w latach sześćdziesiątych i siedemdziesiątych paradoksalnie przyczyniły się do wzrostu zainteresowania tą tematyką wśród naukowców młodego pokolenia. Coraz więcej badaczy sięga także po materiały wydane w języku jidysz, które od lat czekają na opracowanie oraz przekład i udostępnienie ich szerszej publiczności. Zaprezentowana $\mathrm{w}$ niniejszym artykule literatura to zaledwie wycinek tego, co ukazało się na temat getta łódzkiego. Z całą pewnością historiografia Zagłady nie milczy na temat getta łódzkiego, ale gettu łódzkiemu brak pewnej siły przebicia, którą ma np. getto warszawskie. $\mathrm{W}$ dużym stopniu zaważyły na tym uwarunkowania historyczne, specyfika getta łódzkiego, jak również kontrowersyjna i niejednoznacza postać Chaima Rumkowskiego. 


\begin{abstract}
The state of research of the Holocaust literature on the example of the Lodz ghetto. The project of the Lodz ghetto bibliography

The article discusses the world's literature devoted to the history of the Lodz ghetto published since 1943. It includes articles as well as books printed in various languages, which haven't been translated into Polish or English up to nowadays. The aim of the article is to present the Lodz ghetto literature focusing on different areas like cultural life in the Lodz ghetto, German and Jewish administration, chief of the Judenrat Chaim Rumkowski and memoirs. The article describes also memorial books devoted to Lodz, which have never been translated from Yiddish into Polish. Moreover the article deals with the reasons why historians aren't interested in the history of the Lodz ghetto. It also presents the project which aim is to gather literature of the ghetto worldwide.
\end{abstract}




\section{Załącznik 1}

\section{Księga Pamięci Łodzi (1943 r.)}

Do Prezydenta Roosvelta

Do byłego gubernatora Lehmana

Luis Opert - Łódzka Księga Pamięci

Samuel Milman - Łódź nasze rodzinne miasto

A. Alperin - Żydowska Łódź

Abraham Bik - Łódzki rabin

Icchok Lichtensztajn - Samuel Hirszenberg

Sz. Tenenbojm - Enrike Glicensztajn w Łodzi

Icchok Lewin - Tajna Komisja Ewakuacyjna

A. L. Zelmanowicz - Izrael Lichensztajn

I. Rafski - Łódzkie żydowskie towarzystwa

Moris - Zilbercwajg - Teatr żydowski w Łodzi

Regina Feldon - Na ruinach Łodzi

S. Nutkowicz - Dr. Aleksander Margolis

Dr Dawid Lwowicz - 20 lat „ORT’u” w Łodzi

Regina Feldon - Pierwsze pozdrowienie z getta

M. Brand - W Litzmannstadt

Dr Jakub Szacki - Gustaw Ajzner

A.L. - Imiona ich będą świecić przez pokolenia

Zalman Zilbercwajg- Jeszajahu Uger

I.Ch. Radoszycki - Trubadur Herszele

Jakub Kener - Arie Lejb Holenderski

A.L. Zelmanowicz - Przeżycia łódzkiej rodziny Flichtling

Josef Okrutny - Zgony i samobójstwa

Co się stało z pomnikiem T. Kościuszki i z Helenówkiem

Dawid Fefer - Pamięć (wiersz)

Mojżesz Broderson - Faszystowski „humor”

Icchok Jonasowicz - Jakie było „niemieckie” miasto?

Wśród hitlerowskich bestii

I.K. Radoszycki - Zagłada Łodzi

Zjednoczony Komitet Pomocy dla Miasta Łodzi

Luis I. Libowicz - Łódzkie towarzystwa w Ameryce

A.Lejeles - Łódź (wiersz)

I.A.Roncz - Łódzkie kominy (wiersz)

Icchak Berliner - Co teraz poczną (wiersz)

Mirl Erdberg-Szatan - Drogie dni (wiersz)

Filip Lasman - Dwa raporty finansowe

Aleksander Kahan - Działalność Jointu w Łodzi

M. Blumensztok - Pomoc „Federacji” dla Łodzi

Icchak Kacenelson - Przez telefon (wiersz) 


\section{Załącznik 2}

\section{Żydowska Lódź: księga pamięci}
A. Cukiert - Uzasadnienie
Y. Kersz - Żydowska Łódź

\section{Lódź w okresie międzywojennym}

I. Okrutny - Łódź - moje miasto rodzinne

I. Okrutny - Profile literackie

Dr H. Rużner - Żydowscy lekarze

Sz. Rogoziński - Łódź jaką pamiętam

Dr J. Rapaport - Pamięci liceum w Łodzi

M. Szlezinger - Łódzkie Studio Teatralne „Hazomir”

M. Zilbercwajg - Fragmenty z łódzkiego leksykonu teatralnego

I. Landberg - Żydowski Związek Drukarzy

A. Cimerman - Łódzcy Żydzi

A. Cimerman - Nie pytaj... (wiersz)

na podstawie Chajma L. Fuksa - Żydowska prasa w Łodzi

(Stefan Kalus) - Żydowscy dziennikarze w polskiej prasie

\section{Zagłada Lodzi}

M. Ajzenbud - Kronika łódzkiego getta

A. Cukiert - Tak przeżyliśmy

Szewa Glas-Wiener - Dzieci w getcie

M. Białkower - Życie kulturalne w getcie łódzkim

M. Białkower - Słuchacze radia w getcie

A. Biederman - Nie wolno stracić człowieczeństwa

A. Weinberg - Walka o życie

P. Rosenblum-Perelman - 38 dziewcząt z getta łódzkiego

H. Bermitz - Żyd w getcie łódzkim

Genia Bornstein - Uwagi

Y. Einhorn - Pamięci ojca i matki

A. Wiśniewska - Moje wspomnienia

Y. Rosenberg - Nawet ruiny płonęły

Y. Rosenberg - Dwa wiersze

W. H. Even - Mój zrujnowany dom (wiersz)

J. Szpigiel - Los dwóch pisarzy z getta

J. Szpigiel - Dwa wiersze

Fragmenty z dzienników - B. Wiener, J. Poznański

Ch. Rosenfarb - Deszcz... deszcz... deszcz (wiersz); muzyka B. Kalusziner

B. Racheson - David Cholodenko (Neta Isserov)

Mordechai Yolis - wiersz 


\section{Łódź po wojnie}

Sz. Rogoziński - Po wojnie

Ben-Israel - Historia pomnika w Łodzi

Pomnik upamiętniający sześć milionów męczenników (Melbourne)

Pamięci męczenników

Yizkor

A. Cukiert - "El Male Rachamim” [modlitwa za zmarłych]

Lista męczenników

Część angielska 
Załącznik nr 3

\section{Bibliografia getta łódzkiego}

\section{5-2012}

1. Historia

1.1. Zagadnienia ogólne

1.2. Obóz dla dzieci polskich

1.3. Obóz cygański

1.4. Radegast

1.5. Park Ocalałych

1.6. Mordechaj Chaim Rumkowski

1.7. Żydowska administracja getta

1.8. Niemiecka administracja

1.9. Hans Biebow

1.10. Kulmhof am Ner

2. Wspomnienia $\mathrm{z}$ getta łódzkiego

2.1. Biografie

2.2. Poezja

2.3. Dzienniki

2.4. Proza

3. Kultura i sztuka getta łódzkiego

3.1. Sztuki plastyczne

3.2. Muzyka

3.3. Teatr

3.4. Życie literackie

3.5. Życie religijne

3.6. Biblioteki

3.7. Edukacja

3.8. Fotografie

4. Filmy o getcie

5. Wystawy

5.1. Katalogi wystaw

5.2. Recenzje wystaw

6. Konferencje

7. Materiały edukacyjne

8. Szlaki turystyczne getta

9. Varia 